\title{
Quality of broiler meat of the free-range type submitted to diets containing alternative feedstuffs
}

\author{
[Qualidade da carne de frangos de corte do tipo caipira submetidos a dietas contendo \\ alimentos alternativos] \\ P.B. Faria ${ }^{1}$, J.O. Vieira ${ }^{1}$, X.R. Souza $a^{2}$, M.F.M. Rocha ${ }^{1}$, A.A. Pereira ${ }^{5}$ \\ ${ }^{1}$ Universidade Federal de Lavras, Lavras, MG \\ ${ }^{2}$ IFMT - Campus São Vicente - Santo Antonio do Leverger, MT \\ ${ }^{3}$ IFMG - Campus Bambuí, Bambuí, MG
}

\begin{abstract}
The work had the intention of investigating the effect of the use of alternative feeds as part replacers in diet-formulating, evaluating the characteristic physicochemical alterations and centesimal composition of the free-range chicken. In the experiment a total of 192 (one hundred and ninety-two) birds of the Pescoço Pelado (Label Rouge) strain arranged in a completely randomized design (CRD) formed by 4 treatments (Treatment 1 (Control), Treatment 2 (10\% of the inclusion of rice bran), Treatment 3 (10\% of the inclusion of ground cassava leaf) and Treatment 4 (10\% of the inclusion of ground leucaena hay) with 8 replicates per treatment were used. The results revealed greater values of $b^{*}$ (yellow), Saturation $\left(C^{*}\right)$ and $\mathrm{pH}$ for broiler meat with inclusion of ground cassava leaf and leucaena, while for the other variables of physicochemical composition, no influences of the treatments were not found. For centesimal composition the treatments showed greater values of moisture in relation to the control treatment. For sex, only a difference for the content of $\mathrm{b}^{*}$ and $\mathrm{C}^{*}$ was found, with higher values for female. The use of the alternative feedstuffs has not revealed marked influences on the chemical composition and quality parameters of free-ranging chicken's meat with the use of replacement up to $10 \%$ in the diets.
\end{abstract}

Keywords: Label Rouge, Cassava leaf, physicochemical

\section{RESUMO}

O trabalho teve como objetivo analisar o efeito do uso alimentos alternativos como substitutos parciais na formulação das rações, avaliando as alterações características físico-químicas e de composição centesimal de frango caipira. No experimento foi utilizado um total de 192 (cento e noventa e duas) aves da linhagem Pescoço Pelado (Label Rouge), sendo organizado através de um Delineamento Inteiramente ao acaso (DIC) formado por 4 tratamentos (Tratamentol (Controle), Tratamento 2 (10\% de inclusão de Farelo de Arroz), Tratamento 3 (10\% de inclusão da Folha da Mandioca Triturada) e Tratamento 4 (10\% da inclusão de Feno de Leucena Triturado) com 8 repetições por tratamento. Os resultados revelaram maiores valores de $b^{*}$ (amarelo), Índice de Saturação $\left(C^{*}\right)$ e $\mathrm{pH}$ para carne de frango com inclusão da Folha de Mandioca e Leucena triturada, enquanto as demais variáveis de composição físicoquímica não foram verificado influência dos tratamentos. Para composição centesimal os tratamentos apresentaram maiores valores de umidade em relação ao tratamento controle. Para sexo, somente foi verificada diferença para o teor de $b^{*} e C^{*}$, com maiores valores para fêmea. $O$ uso dos ingredientes alternativos não revelaram influências marcantes sobre a composição química e parâmetros de qualidade das carnes de frango caipira com o uso de substituição até $10 \%$ nas rações.

Palavras-chave: Pescoço Pelado, Mandioca, físico-químico

Recebido em 2 de março de 2011

Aceito em 27 de janeiro de 2012

E-mail: peterbfvet@yahoo.com.br 


\section{INTRODUCTION}

In broiler farming with alternative systems, the variation in the diets, use of late-growing strains, increased mobilization and slaughter are aspects which can impact the sensorial characteristics of meat.

Generally consumers think of the industrial chicken meat as lacking in flavor and of soft aspect. However, in free-range and semiconfined chicken raising systems, those negative aspects are overcome, for the animals are slaughtered when older, which confers increase in flavor, in pursuance of the sexual maturity and reduction in tenderness due to the increased total percentage of collagen associated with decreased solubility of that protein (Zanusso and Dionello, 2003).

In the broiler poultry farming sector, chicken rearing in alternative or "free-range" system is a profitable alternative for both small and medium farmers in a market with a great number of consumers willing to pay distinct prices for this product. The Brazilian free-range chicken system was regulated by the Ministry of Agriculture and Supply (MAPA), through the DIPOA Department of Inspection of Products of Animal Origin in the OFFICIAL CIRCULAR DOI/DIPOA Number 007/99 in 19/05/99 (Brazil, 1999). According to the MAPA directive, chicken named "Free-range chicken" or "Colonial Chicken" or "Free-range type or style chicken" or Colonial type or style" is chicken whose feeding is constituted of feedstuffs exclusively of plant origin, the use of growth promoters being prohibited. The birds are free in the field, their rearing being extensive and $3 \mathrm{~m}^{2}$ of pasture per bird is recommended. Slaughter takes place at the minimum age of 85 days. The strains used should be suitable for that purpose, the commercial strains fit for broiler chicken not being allowed.

In the productive chain, the search for alternative feeds which can make the production of freerange birds viable is a way to adequately and economically replace the traditionally used feedstuffs. Cassava is one of these alternatives to replace traditional cereals, the shoot being a good option to offer protein at low cost due to its vitamin, mineral and protein content (Silva et al., 2000). Furthermore, the following can still be cited as alternative feeds for broiler production: Leucaena leaf meal (Leucaena leucocephala), Rice and Pigeon Pea Meal (Cajanus cajan).

The objective of this work was to investigate the effect of the use of alternative feeds as part replacers for the feedstuffs used in the formulation of diets, evaluating the alterations relative to the quality of meat with the evaluation of the physicochemical parameters and centesimal composition.

\section{MATERIAL AND METHODS}

The experiment was conducted at the IFMT farm Campus São Vicente, situated at the São Vicente range, $80 \mathrm{~km}$ from Cuiabá-MT, in the facilities of the Experimental Shed of Poultry Production. In the study, a total of 192 (one hundred and ninetytwo) birds of the Pescoço Pelado strain (Label Rouge) were used, arranged through a Completely Randomized Design (CRD) made up of 4 treatments (isoprotein diets), 2 sex (Male and Female) and 8 (eight) replicates per treatment, amounting to 64 experimental units. Each experimental unit was made up of 3 birds, amounting to 192 birds. The treatments were applied at finish period (29 to 84 days), whilst at starter period all the birds were given the same diet. The treatments were: Treatment1 (Control), Treatment 2 (10\% inclusion of Rice bran), Treatment 3 (10\% inclusion of Ground Leaf Meal with $16.42 \%$ Crude Protein (CP) and $85.16 \%$ Dry Matter (DM)), Treatment 4 (10\% inclusion of Ground Leucaena Hay, with $15.60 \%$ of CP and $87.08 \%$ of DM). To establish the experiments 1-day old chickens of both sexes were utilized, being handled regularly till slaughter age (85 days).

The diet fed was composed of two dietary formulations (Table 1) prepared in the Feed Factory of the Animal Science sector of IFMT São Vicente Campus. The starter diet was the same for all the birds, being given from the $1^{\text {st }}$ (first) to the $28^{\text {th }}$ (twenty-eighth) day of age. From the $29^{\text {th }}$ (twenty-ninth) day to age of slaughter, the diets were fed according to each treatment. 
Quality of broiler...

Table 1. Feedstuffs and compositions of the starter and finish diets for the chickens during the experimental period ${ }^{1}$

\begin{tabular}{|c|c|c|c|c|c|}
\hline Feedstuffs & Starter diet & T1 & T2 & T3 & T4 \\
\hline Ground Corn & 63.00 & 70.00 & 62.05 & 62.70 & 62.92 \\
\hline Soybean meal & 33.70 & 27.00 & 24.95 & 24.30 & 24.08 \\
\hline Rice Bran & - & - & 10.00 & - & - \\
\hline Leucaena Hay & - & - & - & 10.00 & - \\
\hline Cassava Leaf & - & - & - & - & 10.00 \\
\hline Dicalcium phosphate & 2.00 & 1.80 & 1.80 & 1.80 & 1.80 \\
\hline Calcitic limestone & 0.85 & 0.75 & 0.75 & 0.75 & 0.75 \\
\hline Salt $(\mathrm{NaCl})$ & 0.20 & 0.22 & 0.22 & 0.22 & 0.22 \\
\hline $\begin{array}{l}\text { Vitamin and Mineral } \\
\text { Supplement }\end{array}$ & 0.20 & 0.20 & 0.20 & 0.20 & 0.20 \\
\hline Probiotic $^{3}$ & 0.03 & 0.03 & 0.03 & 0.03 & 0.03 \\
\hline \multicolumn{6}{|l|}{ Calculated values } \\
\hline Metabolizable Energy (Kcal/kg) & 2.896 & 2.972 & 2.898 & 2.696 & 2.699 \\
\hline Lysine $(\%)$ & 1.13 & 0.97 & 0.90 & 0.83 & 0.83 \\
\hline Methionine (\%) & 0.34 & 0.30 & 0.29 & 0.26 & 0.26 \\
\hline Protein & 21.00 & 18.00 & 18.00 & 18.00 & 18.00 \\
\hline \multicolumn{6}{|l|}{ Analyzed values } \\
\hline Dry matter & 88.17 & 88.23 & 88.06 & 88.35 & 88.40 \\
\hline Ashes & 5.52 & 4.59 & 5.23 & 5.15 & 5.27 \\
\hline Ether extract & 1.29 & 1.37 & 2.30 & 1.60 & 2.10 \\
\hline Protein & 20.71 & 18.51 & 17.16 & 16.61 & 15.36 \\
\hline
\end{tabular}

${ }^{1}$ T1 - Control Treatment, T2 - Treatment with $10 \%$ inclusion of Rice bran, T3 - Treatment with 10\% inclusion of Ground Cassava Meal, T4 - Treatment with $10 \%$ inclusion of Ground Leucaena Hay; ${ }^{2}$ Levels of security per kg of the product: Copper (min) 7000.0mg, iron ( $\mathrm{min}) .50.0 \mathrm{~g}$, Iodine (min) $1450.0 \mathrm{mg}$, Manganese (min.) 67.5g, zinc (min.) $45.5 \mathrm{~g}$, folic acid (min) $150.0 \mathrm{mg}$, pantothenic acid (min.) $6165.0 \mathrm{mg}$, niacin ( $\mathrm{min}) 13.0 \mathrm{~g}$, selenium (min) 500.0mg; vitamin A (min.) $3466680.0 \mathrm{IU}$, vitamin B12 (min) $6760.0 \mathrm{mcg}$, vitamin B2 (min) $2080.0 \mathrm{mg}$, vitamin B6 (min) 260.0mg, vitamin D3 (min .) 1282671.0IU, vitamin E (min.) $3120.0 \mathrm{IU}$, vitamin K3 (min) 635.0mg; ${ }^{3}$ CALSPORIN $10 ®$ - Bacillus subtilis: $1 \times 10^{9} \mathrm{ufc} / \mathrm{g}$

The birds were raised in the experimental area designated for rearing free-range chickens. The total area is about $2,025 \mathrm{~m}^{2}$ divided into 16 boxes. Each box presented a grazing area of about $100 \mathrm{~m}^{2}$, and a covered area of $3.2 \mathrm{~m}^{2}$, which affords a capacity to house up to 30 birds per box. The birds were separated in the boxes per sex and distributed according to each treatment; management was performed according to the patterns related to the farming of free-range chickens.

At starter period, the birds were given feed and water ad libitum until day 28; they were vaccinated against the Newcastle, Fowlpox and Avian Infectious Bursitis diseases in the drinking water, at 7 and 21 days of age according to the recommendation from the vaccines' manufacturers. From the $29^{\text {th }}$ day forward, the birds began having access to the grazing area of the boxes, the feeds being given once a day.
Slaughter was performed in the facilities of the cold storage building existing at IFMT Campus São Vicente (Santo Antonio do Leverger-MT) through the humanitarian method and use of good hygiene practices. The birds were weighted after slaughter, packed individually into plastic bags and carried into the cooler $\left(+1^{\circ} \mathrm{C}\right)$. The cuts were deboned 24 hours post mortem, packed, identified, frozen and kept at $-18^{\circ}$ Celsius. Samples of the Pectoralis major muscle (breast) were collected for the fulfillment of the physicochemical determinations and centesimal composition. The analyses were conducted after thawing the cut at $4^{\circ} \mathrm{C}$ for 24 hours.

The determination of final $\mathrm{pH}$ in the breast was done with DIGIMED DM-20 potentiometer coupled to an electrode through incisions done with the tip of a knife on the cranial region on the right side. 
The color determinations were performed with MINOLTA CR 200b colorimeter (Osaka Japan), operating in the CIEL*a*b* system, with illuminant D65. The readings were done on three distinct points on the inside face of the cranial position of the left pectoralis major muscle (Souza, 2004). Previously, the samples were exposed to light for 30 minutes before the readings. The values of the color components utilized in the statistical analyses were the means of the three readings performed per bird for each experimental unit. The saturation $\left(\mathrm{C}^{*}\right)$ and hue angle $\left(\mathrm{h}^{*}\right)$ indexes were calculated using the following formulas (Ramos and Gomide, 2007): $\mathrm{C} *=\left(\mathrm{a}^{*} \mathrm{~b} * 2+2\right) 1 / 2 \mathrm{~h} *=\tan -1(\mathrm{~b} * / \mathrm{a} *)$.

To determine cooking loss (CL), the breast samples were weighted in semi-analytical scales, METTLER M P1210 (Toledo, Brazil), wrapped in aluminum paper and submitted to cooking on an electrical plate at $150^{\circ} \mathrm{C}$. When the samples reached $72^{\circ} \mathrm{C}$ they were removed from the plate, cooled at room temperature and weighted (AMASA, 1978; Souza, 2004; Faria et al., 2009). For the CL values used in the statistical analysis, the means of the differences between the weights before and after cooking each of the experimental units were obtained and converted into percentages.

The samples cooked for CL determination were prepared for tenderness evaluation. The samples cooked were cut into pieces with $2.0 \times 1.0 \times 1.0 \mathrm{~cm}$ sizes, with the greatest length in the lengthwise direction of the muscle fibers according to Froning and Uijttenboogarte (1988) methodology. The samples were sectioned in the crosswise direction of the muscle fibers, utilizing a Warner Bratzler probe coupled to a texturometer TA XT-2 model, gauged to cut at the speed of $2 \mathrm{~mm} / \mathrm{s}$, sensitivity of $0.250 \mathrm{~N}$ and unit in $\mathrm{kg} / \mathrm{cm}^{2}$.

The samples for proximal analysis were prepared with the removal of skin and aponeurosis, followed by homogenization. The analyses of moisture, protein, ether extract and ashes were performed according to Horwitz (1990), in triplicate.

The data was analyzed with the support of the SISVAR® program. The variables with responses of significant effect in the analysis of variance for the Treatment and Sex and/or interaction among those variables factors were submitted to the Scott-knott test (5\% significance levels).

\section{RESULT AND DISCUSSION}

The results of the variance analysis of the factors studied for physicochemical characteristics and centesimal composition are shown in Table 2.

Table 2. Analysis of data variance of physicochemical characteristics of free-ranging broiler meat related to the treatments, sex and interaction

\begin{tabular}{lllll}
\hline \multirow{2}{*}{ Variables } & \multicolumn{2}{l}{ Values $\mathrm{P}^{1}$} & & \\
\cline { 2 - 4 } $\mathrm{L}^{*}$ & Treatments & Sex & Treatments x Sex & CV $(\%)$ \\
$\mathrm{a}^{*}$ & 0.1072 & 0.3309 & 0.9940 & 2.68 \\
$\mathrm{~b}^{*}$ & 0.2067 & 0.5737 & 0.5132 & 71.41 \\
$\mathrm{C}^{*}$ & 0.0001 & 0.0080 & 0.4461 & 13.10 \\
$\mathrm{H}^{*}$ & 0.0001 & 0.0091 & 0,4001 & 11.64 \\
$\mathrm{CL}$ & 0.2875 & 0.4038 & 0.7928 & 6.23 \\
$\mathrm{pH}$ & 0.2051 & 0.1196 & 0.4950 & 14.58 \\
$\mathrm{SF}$ & 0.0500 & 0.3341 & 0.0710 & 0.84 \\
Moisture & 0.8315 & 0.4868 & 0.6512 & 16.91 \\
Ashes & 0.0174 & 0.3511 & 0.9555 & 1.07 \\
Protein & 0.3854 & 0.3854 & 0.8912 & 14.97 \\
Ether Extract & 0.2235 & 0.4816 & 0.8877 & 6.60 \\
\hline
\end{tabular}

$1-$ Test $\mathrm{F}$ (levels of significance of $5 \%$ ); $\mathrm{L}^{*}=$ brightness; $\mathrm{a}^{*}=$ redness; $\mathrm{b}^{*}=$ yellowness; $\mathrm{C}^{*}=$ saturation indexes; $\mathrm{H}^{*}$ $=$ hue angle; $\mathrm{CL}=$ Cooking Loss; $\mathrm{pH}=$ Finish $\mathrm{pH} ; \mathrm{SF}=$ Shear Force 
The statistical analysis of the data did not reveal interaction between treatment and sex $(\mathrm{P}>0.05)$ for the analyzed variable. Nevertheless, there were isolated effects of the alternatives feeds on the meat of yellowness $\left(b^{*}\right)$, Saturation $\left(\mathrm{C}^{*}\right), \mathrm{pH}$ and moisture, while effect of sex was only found for variables $b^{*}$ e $C^{*}$.

The variables $\mathrm{L}^{*}$ (luminosity), $\mathrm{a}^{*}$ (red content), Cooking Loss (CL), Shear Force (SF), Ashes, Protein and Ether Extract were not influenced by treatments and sex.

The means of luminosity in this study ranged from 47.05 to 48.14 (Table 3) regardless of the treatment used. Faria et al. (2009) also reported no difference in relation to the content of luminosity for breast meat, regardless of the strain utilized and found means similar to that of this work, varying from 47.95 to 48.06. Similar behavior was also reported by Souza (2004), with means from 46.22 to 46.77 for both Paraíso Pedrês and Pescoço Pelado, and by Santos et al. (2005), with means from 48.62 to 50.19, form Paraíso Pedrês and Isa Label chickens. In the same way, no effect of sex was found, confirming the findings of Santos et al. (2005), Lonergan et al. (2003) and Fanatico et al. (2005).

Table 3. Means of the physicochemical components and centesimal composition of free-range chickens based on feeding and sex

\begin{tabular}{|c|c|c|c|c|c|c|}
\hline \multirow[t]{2}{*}{ Variables } & \multicolumn{4}{|c|}{ Treatments } & \multicolumn{2}{|l|}{ Sex } \\
\hline & T1 & $\mathrm{T} 2$ & T3 & T4 & Male & Female \\
\hline $\mathrm{L}^{*}$ & $47.78 \mathrm{a}$ & $48.14 \mathrm{a}$ & $47.43 a$ & $47.05 \mathrm{a}$ & $47.76 a$ & $47.44 \mathrm{a}$ \\
\hline$a^{*}$ & $0.81 \mathrm{a}$ & $1.09 \mathrm{a}$ & $0.97 \mathrm{a}$ & $1.38 \mathrm{a}$ & $1.11 \mathrm{a}$ & $1.01 \mathrm{a}$ \\
\hline$b^{*}$ & $8.76 b$ & $7.67 \mathrm{c}$ & $9.49 a$ & $10.18 \mathrm{a}$ & $8.65 b$ & $9.40 \mathrm{a}$ \\
\hline $\mathrm{C}^{*}$ & $8.83 b$ & $7.78 \mathrm{c}$ & $9.58 \mathrm{a}$ & $10.30 \mathrm{a}$ & $8.76 b$ & $9.48 \mathrm{a}$ \\
\hline $\mathrm{H}^{*}$ & $84.61 \mathrm{a}$ & $81.57 \mathrm{a}$ & $84.06 \mathrm{a}$ & $82.15 \mathrm{a}$ & $82.55 a$ & $83.64 \mathrm{a}$ \\
\hline CL & $19.95 \mathrm{a}$ & $21.73 \mathrm{a}$ & $21.84 \mathrm{a}$ & $21.43 \mathrm{a}$ & $20.69 a$ & $21.79 \mathrm{a}$ \\
\hline $\mathrm{pH}$ & $5.78 b$ & $5.78 b$ & $5.81 \mathrm{a}$ & $5.82 \mathrm{a}$ & $5.79 a$ & $5.80 \mathrm{a}$ \\
\hline SF & $1.95 \mathrm{a}$ & $2.04 \mathrm{a}$ & $1.94 \mathrm{a}$ & $1.97 \mathrm{a}$ & $1.95 \mathrm{a}$ & $2.00 \mathrm{a}$ \\
\hline Moisture & $73.72 b$ & $74.38 \mathrm{a}$ & $74.62 \mathrm{a}$ & $74.19 \mathrm{a}$ & $74.32 \mathrm{a}$ & $74.14 \mathrm{a}$ \\
\hline Ashes & $1.24 \mathrm{a}$ & $1.18 \mathrm{a}$ & $1.14 \mathrm{a}$ & $1.22 \mathrm{a}$ & $1.17 \mathrm{a}$ & $1.21 \mathrm{a}$ \\
\hline Protein & $24.73 a$ & $24.23 \mathrm{a}$ & $23.56 \mathrm{a}$ & $24.02 \mathrm{a}$ & $24.28 \mathrm{a}$ & $23.99 \mathrm{a}$ \\
\hline Ether Extract & $0.68 \mathrm{a}$ & $0.64 \mathrm{a}$ & $0.69 \mathrm{a}$ & $0.75 \mathrm{a}$ & $0.71 \mathrm{a}$ & $0.67 \mathrm{a}$ \\
\hline
\end{tabular}

Means followed by distinct small letters in the row differ by the Scott-Knott test $(\mathrm{P}<0.05)$; T1 - Control Treatment, T2 - Treatment with $10 \%$ inclusion of Rice Bran, T3 - Treatment with 10\% inclusion of Ground Cassava Leaf, T4 Treatment with $10 \%$ inclusion of Ground Leucaena Hay; $\mathrm{L}^{*}=$ brightness; $\mathrm{a}^{*}=$ redness; $\mathrm{b}^{*}=$ yellowness; $\mathrm{C}^{*}=$ saturation indexes; $\mathrm{H}^{*}=$ hue angle; $\mathrm{CL}=$ Cooking Loss; $\mathrm{pH}=$ Finish $\mathrm{pH} ; \mathrm{SF}=$ Shear Force.

For $\mathrm{a}^{*}$, the means ranged from 0.81 to 1.38 and were not affected by feeding and sex. The results of the literature, in general, showed no influence of sex on the red contents (Fanatico et al., 2005; Lonergan et al., 2003; Santos et al., 2005; Souza, 2004). However, the values of this work are quite inferior to those reported by Fanatico et al. (2005), with $\mathrm{a}^{*}$ means of 3.92 and 3.94; Santos et al. (2005), with 3.49 and 3.40 means and; Faria et al. (2009) with mean from 4.58 to 5.30.

The treatments with Cassava Leaf and Leucaena Hay provided meats with increased contents of yellowness (Table 3). Those higher values may be due to increased consumption of carotenoid pigments present in the feeds, since the leaves were used for the preparation of these ingredients. Similarly, the females showed greater yellow coloration for breast meat. These results are in accordance with the reports by Fanatico et al. (2005), Souza (2004) and Faria et al. (2009) who found increased intensities in the content of Yellow for females, regardless of the strain utilized. That behavior may be related to the sexual dimorphism of birds, where females tend to present greater development of the breast and this would be accompanied by greater accumulation of carotenoid pigments, characterizing a more yellow coloration.

The value of the saturation index $\left(\mathrm{C}^{*}\right)$ indicates the purity and intensity of color (Pomeranz and Meloan, 1971), being directly influenced by the values of $a^{*}$ and $b^{*}$. The results indicated that 
with the use of cassava leaves and Leucaena on females the values of $C^{*}$ were more intense and is due to the influence of the amount of yellow present in these meats. Thus, these results indicate that the yellow color was more intense in these two treatments (Cassava and Leucaena) and in females (Table 3). However, the hue angle $(\mathrm{h} *)$ did not change the color yellow, regardless of treatment and sex.

In general, the work showed no influence of sex on the values of Water Holding Capacity (Fanatico et al., 2005; Musa et al., 2006; Santos et al., 2005), which confirms the results of this work where differences in relation to CL were found, with mean ranging from 19.95 to $21.84 \%$. Faria et al. (2009) found means varying from 21.36 to $24.98 \%$ for the Pescoço Pelado strain, regardless of slaughter age. Nevertheless, the author found influence of sex, with highest means of CL for males.

The treatments with Leucaena Leaf and Cassava resulted in less reduction of the $\mathrm{pH}$ values of the breast meat. Likely, the lowest values of energy in the diet may have caused a lower deposition of muscular glycogen in relation to the control treatment as well as with the use of Rice Bran. On the other hand, Almeida et al. (2002), studying the broiler diets, found no differences in the $\mathrm{pH}$ values of the breast at different slaughter ages. No influence of sex was found, supporting the findings by Lonergan et al. (2003), Quentin et al. (2003), Santos et al. (2005) and Almeida et al. (2002). However, Faria et al (2009), reports differences between sex, with means of 5.89 for males and of 5.83 for females.

In literature, some works show a negative correlation between $\mathrm{L}^{*}$ indexes and $\mathrm{pH}$ values, since those influence the water-holding capacity (Bihan-Duval et al., 2001; Musa et al., 2006), nevertheless, in this work there were no influences on the values of $\mathrm{CL}$ and $\mathrm{L}^{*}$, regardless of feeding and sex.

The treatments and sex did not influence the SF values, which ranged from 1.94 to $2.04 \mathrm{~kg} / \mathrm{cm}^{2}$. Souza (2004) reported values close to the ones in this work for birds slaughtered at 85 days, with a mean of $2.00 \mathrm{~kg} / \mathrm{cm}^{2}$. On the other hand, Castellini et al. (2002a) reported a mean of $2.71 \mathrm{~kg} / \mathrm{cm}^{2}$ at 81 days for chickens raised in the organic system.
Generally in literature, following the same trend of this work, no influences of sex upon chickens' breast meat tenderness are reported (Lonergan et al.; 2003; Souza, 2004; Santos et al., 2005). On the other hand, Fanatico et al. (2005) found increased shear force in male animals, when compared with the females.

The values of protein, in general, kept steady, not undergoing any influence of the different treatments and sex, supporting the reports in the literature, which also showed no difference among strains (Castellini, 2005; Castellini et al., 2006; Grashorn and Clostermann, 2002), rearing systems and slaughter age (Castellini et al., 2002b).

The different feedstuffs utilized in the diets promoted alteration in the values of moisture with greater means in relation to the Control Treatment (Table 3). These results show that the treatments used with these feedstuffs may have provided greater myogenesis activity in relation to lipogenesis, in spite of there being no difference in relation to the lipid contents between the treatments and sex. Castellini et al. (2002a) found that the birds reared in organic system presented greater moisture values and low fat values.

Regarding to the lipid values of meat, the results were opposite to the reports in literature, which show the effect of sex. Faria et al. (2009) reported difference between sexes at 85 days, with greater values for females $(0.91 \%)$, compared to males (0.62\%). Souza (2004) verified that at 110 days, the females presented higher lipids means in the breast than the males; similar results were also reported by Lonergan et al. (2003).

In the literature, the works in general showed no differences in the ash contents of the breast meat for animals reared in organic (Castellini et al., 2002b; Castellini, 2005; Castellini et al., 2006) and alternative systems (Faria et al., 2009), supporting the results found in this work. The means found ranged from 1.14 to $1.24 \%$, being similar to those reported by Faria et al. (2009) from $1.02 \%$ to $1.33 \%$ and higher than the values cited by Souza (2004), from $0.91 \%$ to 1.02 ; Castellini (2005), from $0.61 \%$ to $0.79 \%$; and Castellini et al. (2006), from $0.62 \%$ to $0.76 \%$. 
In the present work, there were no differences for the meat protein content, which presented means from 23.56 to $24.73 \%$. Similarly, no differences in the protein content for the works of Faria et al. (2009), with means from 22.91 to 23.11; Castellini (2005), with means from $22.39 \%$ to $22.76 \%$ and Castellini et al. (2006), with means from $22.32 \%$ and $22.77 \%$.

In general, the animals presented meats with reduced lipid and protein values and higher protein values in the meat regardless of sex and treatment used, when compared to the results found in the literature for chickens reared in freerange, organic and alternative systems.

\section{CONCLUSION}

The results obtained in this work demonstrated that the use of alternative feedstuffs in broiler diets revealed no marked influences on the chemical composition and quality parameters of the meat of free-ranging chickens with the use of replacement up to $10 \%$ in the diets.

\section{ACKNOWLEDGEMENTS}

The authors thank to FAPEMAT for the financial support and scholarship grants and IFMT Campus São Vicente for the support in the conduction of the experiment.

\section{REFERENCES}

ALMEIDA, J.C.L.; MENDES, A.A.; GARCIA, R.G. et al. Efeito do nível de lisina da dieta e do sexo sobre o desempenho e rendimento de carcaça de frango de corte. Braz. J. Poult. Sci., v.4, p.11-18, 2002.

AMASA. Guidelines for cooking sensory evaluation of meat. American Meat Science Association, National Live Stock and Meat Board:Chicago, 1978. 24p.

BIHAN-DUVAL, E.; BERRI, C.; BAEZA, E. et al. Estimation of the genetic parameters of meat characteristics and of their genetic correlations with growth and body composition in an experimental broiler line. Poult. Sci., v.80, p.839-843, 2001.

BRASIL. Ministério Agricultura, Pecuária e Abastecimento. Ofício Circular DOI/DIPOA n.007/99, de 19 de maio de 1999.
CASTELLINI, C. Organic poultry production system and meat characteristics. In: EUROPEAN SYMPOSIUM ON THE QUALITY OF POULTRY MEAT, 17.; EUROPEAN SYMPOSIUM ON THE QUALITY OF EGGS AND EGG PRODUCTS DOORWERTH, 11., World's Poultry Science Association, 2005, The Netherlands. Proceedings... The Netherlands, 2005. p.47-52.

CASTELLINI, C.; DAL BOSCO, A.; MUGNAI, C. et al. Comparison of two chicken genotypes organically reared: oxidative stability and other qualitative traits of the meat. Itali. J. Anim. Sci., v.5, p.355-363, 2006.

CASTELLINI, C.; MUGNAI, C.; DAL BOSCO, A. Effect of organic production system on broiler carcass and meat quality. Meat Sci., v.60, p.219225, 2002a.

CASTELlini, C.; MUGNAI, C.; DAL BOSCO, A. Meat quality of three chicken genotypes reared according to the organic system. Itali. J. Food Sci., v.14, p.401-424, 2002b.

FANATICO, A.C.; CAVITT, L.C.; PILLAI, P.B. et al. Evaluation of slower-growing broiler genotype grown with and without outdoor access: meat quality. Poult. Sci., v.84, p.17851790, 2005.

FARIA, P.B.; BRESSAN, M.C.; SOUZA, X.R. et al. Composição proximal e qualidade da carne de frangos das linhagens Paraíso Pedrês e Pescoço Pelado. Rev. Bras. Zootec., v.38, p.2455-2464, 2009.

FRONING, G.W.; UIJTTENBOOGAART, T.G. Effect of post mortem electrical stimulation on color, texture, $\mathrm{pH}$ and cooking loses of ho and cold deboned chicken broiler breastmeat. Poult. Sci., v.67, p.1536-1544, 1988.

GRASHORN, M.A.; CLOSTERMANN, G. Performance and slaughter characteristics of broiler breeds for extensive production. Arch. Geflügelk, v.66, p.173-181, 2002.

HORWITZ, W. Official methods of analysis of Association of Official Analytical Chemists. 13.ed. Whashington: AOAC, 1990. 1018p.

LONERGAN, S.M.; DEEB, N.; FEDLER, C.A. et al. Breast meat quality and composition in unique chicken populations. Poult. Sci., v.82, p.1990-1994, 2003. 
MUSA, H.H.; CHEN, G.H.; CHENG, J.H. et al. Breed and Sex effect on meat quality of chicken. Inter. J. Poult. Sci., v.5, p.566-568, 2006.

POMERANZ, Y.; MELOAN, C.E. Food Analysis: Theory and practice. 1 st. ed. Westpot Connecticut: The AVI Publishing Company Corporation, 1971, 669p.

QUENTIN, M.; BOUVAREL, I.; BERRI, C. et al. Growth, carcass composition and meta quality response to dietary concentrations in fast-, medium- and slow-growing commercial broilers. Anim. Research, v.52, p.65-77, 2003.

RAMOS, E.M.; GOMIDE, L.A.M. Avaliação da Qualidade de Carnes: fundamentos e metodologias. Viçosa, MG. Ed. UFV, 2007. $599 \mathrm{p}$.

SANTOS, A.L.; SKOMURA, N.K.; FREITAS, E.R. et al. Estudo do crescimento, desempenho, rendimento de carcaça e qualidade de carne de três linhagens de frango de corte. Rev. Bras. Zootec., v.34, p.1589-1598, 2005.
SILVA, H.O.; FONSECA, R.A.; GUEDES FILHO, R.S. Características produtivas e digestibilidade da farinha de folhas de mandioca em dietas de frangos de corte com e sem adição de enzimas. Rev. Bras. Zootec., v.29, p.823-829, 2000.

SOUZA, X.R. Características de carcaça, qualidade de carne e composição lipídica de frangos de corte criados em sistemas de produção caipira e convencional. 2004. 334f. Tese (Doutorado em Ciência dos Alimentos) Universidade Federal de Lavras, Lavras, 2004.

ZANUSSO, J.T.; DIONELLO, N.J.L. Produção avícola alternativa: análise dos fatores qualitativos da carne de frangos de corte tipo caipira. Rev. Bras. Agroc., v.9, p.191-194, 2003. 